University of Chicago Law School

Chicago Unbound

Public Law and Legal Theory Working Papers

Working Papers

2007

\title{
The Complex Climate Change Incentives of China and the United States
}

Cass R. Sunstein

Follow this and additional works at: https://chicagounbound.uchicago.edu/public_law_and_legal_theory

Part of the Law Commons

Chicago Unbound includes both works in progress and final versions of articles. Please be aware that a more recent version of this article may be available on Chicago Unbound, SSRN or elsewhere.

\section{Recommended Citation}

Cass R. Sunstein, "The Complex Climate Change Incentives of China and the United States" (University of Chicago Public Law \& Legal Theory Working Paper No. 176, 2007).

This Working Paper is brought to you for free and open access by the Working Papers at Chicago Unbound. It has been accepted for inclusion in Public Law and Legal Theory Working Papers by an authorized administrator of Chicago Unbound. For more information, please contact unbound@law.uchicago.edu. 


\title{
CHICAGO
}

JoHn M. Olin LAW \& ECONOMICS WORKING PAPER NO. 352

(2D SERIES)

Public LaW and Legal Theory Working Paper No. 176

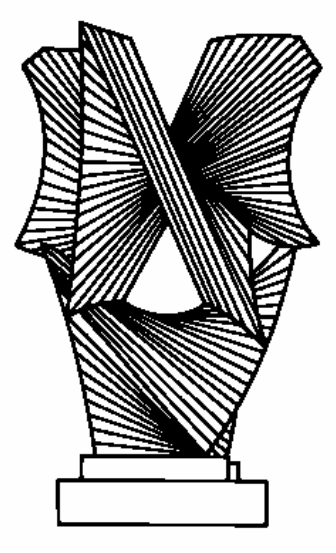

\section{The COMPLeX Climate CHANGE INCENTIVES OF CHINA AND THE UNITED STATES}

Cass R. Sunstein

\section{THE LAW SCHOOL THE UNIVERSITY OF CHICAGO}

\author{
August 2007 \\ This paper can be downloaded without charge at the John M. Olin Program in Law and \\ Economics Working Paper Series: http://www.law.uchicago.edu/Lawecon/index.html and at the \\ Public Law and Legal Theory Working Paper Series: \\ http://www.law.uchicago.edu/academics/publiclaw/index.html \\ and The Social Science Research Network Electronic Paper Collection: \\ http://ssrn.com/abstract_id=1008598
}




\title{
The Complex Climate Change Incentives of China and the United States
}

\author{
Cass R. Sunstein ${ }^{*}$
}

\begin{abstract}
It is increasingly clear that the world would be better off with an international agreement to control greenhouse gas emissions. What remains poorly understood is that the likely costs and benefits of emissions controls are highly variable across nations. Most important, prominent projection suggest that the world's leading emitters--the United States and China-have weak incentives to participate in an agreement that would be optimal from the standpoint of the world. The first problem is that any significant emissions effort would probably be exceedingly expensive for both nations. The second problem is that on prominent projections, the United States and China are unlikely to be the most serious losers from climate change. There are two ways to eliminate the resulting obstacle to an international agreement. The first is through altering the perceived cost-benefit analysis for both countries. The second is through an understanding that both nations, and the United States in particular, are under a moral obligation not to inflict serious harm on the highly vulnerable citizens of Africa, India, and elsewhere. Existing proposals for unilateral action on the part of the United States seem to stem from an unruly mixture of confusion, hope, and a sense of moral obligation. There are also interesting differences between the situations of the two leading emitters: Because China is much poorer and has much lower per capita emissions, it is especially difficult to interest China in taking aggressive steps to reduce its emissions.
\end{abstract}

\section{Introduction}

It is now sufficiently clear that the world as a whole would benefit from an international agreement to control climate change. ${ }^{1}$ For all the continuing controversy, ${ }^{2}$ the central features of a desirable agreement are not obscure. First, all significant

\footnotetext{
${ }^{*}$ Karl N. Llewellyn Distinguished Service Professor of Jurisprudence, Law School and Department of Political Science, University of Chicago. Thanks to Jack Goldsmith, Robert Hahn, Saul Levmore, Eric Posner, and Adrian Vermeule for extremely helpful comments and to Bryan Mulder for excellent research assistance.

${ }^{1}$ See William Nordhaus, The Challenge of Global Warming: Economic Models and Environmental Policy (2007), available at http://www.econ.yale.edu/ nordhaus/DICEGAMS/dice_mss_060707_pub.pdf; Nicholas Stern, The Economics of Climate Change (2007). A exceedingly valuable discussion is Richard B. Stewart and Jonathan B. Wiener, Reconstructing Climate Policy: Beyond Kyoto (2003)

${ }^{2}$ Compare Nordhaus, supra note (calling for modest carbon taxes) and Bjorn Lomborg, Cool It (2007) (same) with Stern, supra note (calling for aggressive carbon taxes). The difference between Nordhaus and Lomborg on the one hand and Stern on the other stems largely from a disagreement over the appropriate discount rate; Stern's choice of a near-zero rate leads to an analysis that favors far more aggressive cuts. Stern does not offer nation-by-nation assessments of the costs and benefits of different possible scenarios. Nordhaus' most recent work, see id., is based on global assessments and does not show how different nations would be affected by possible courses of action.
} 
contributors, most prominently the United States and China, should be included, because the benefits of greenhouse gas reductions depend on broad participation. ${ }^{3}$ A partial agreement, even one that includes (say) all of the nations of Europe, will make an exceedingly modest dent in anticipated warming. ${ }^{4}$ Second, economic incentives are indispensable. A carbon tax or a global emissions trading system would be far cheaper than more rigid alternatives. ${ }^{5}$ Third, emissions reductions should be relatively modest at the inception, and they should grow or "ramp up" over time. ${ }^{6}$ Some people disagree with this third proposition and support aggressive reductions at an early date ${ }^{7}$; but the consensus is against them. ${ }^{8}$

My central goal in this Article is to explore a serious obstacle to achievement of an agreement that is, by most accounts, in the world's interest. The obstacle lies in the fact that on prominent recent projections, an agreement that is in the interest of the world as a whole is unlikely to be in the interest of China and the United States, the world's leading contributors. It is increasingly clear that the costs and benefits of emissions reductions are highly variable across nations. On prominent projections, neither China nor the United States is anticipated to be among the principal victims of climate change. The circumstances for an international agreement are distinctly unpromising if the leading emitters do not perceive themselves as likely to gain a great deal from emissions reductions.

\footnotetext{
${ }^{3}$ See Sheila Olmstead and Robert N. Stavins, A Meaningful Second Commitment Period for the Kyoto Protocol, The Economists' Voice (May 2007), available at www.bepress.com/ev; Nordhaus, supra note; Stewart and Wiener, supra note.

${ }^{4}$ See Nordhaus, supra note. Consider here the fact that by one assessment, the Kyoto Protocol would itself reduce anticipated warming by only $0.03 \mathrm{C}$ by 2100 , reducing anticipated warming of $1.8 \mathrm{C}$ to $4.0 \mathrm{C}$ by that very modest amount. See William Nordhaus and Joseph Boyer, Warming the World 152 (2000). Even if the Kyoto Protocol would make more of a dent in warming, no one believes that the dent would be large; .4 C would be a reasonable upper bound. On one estimate, for example, the reduction would be between 0.04 and $.10 \mathrm{C}$ for one degree warming by 2100, and between .08 and $.28 \mathrm{C}$ for 2.5 degree warming. See Stewart and Wiener, supra note. On this account, the domestic benefits of Kyoto would be up to .2 prevent of GDP, with the domestic costs being 1 to 2 percent of GDP, by the middle to the end of the twenty-first century. Id. at $45-46$.

${ }^{5}$ See Olmstead and Stavins, supra note; William Nordhaus and Joseph Boyer, Warming the World 15663 (2000); Stewart and Wiener, supra note.

${ }^{6}$ See, e.g., Nordhaus, supra note; Olmstead and Stavins, supra note.

${ }^{7}$ See Nicholas Stern, The Economics of Climate Change (2007).

${ }^{8}$ See Nordhaus, supra note.
} 
To be sure, the current projections are disputed, and the eventual losses might turn out to be quite high ${ }^{9}$; but to the extent that they have accepted the recent projections, the two leading contributors have lacked a strong incentive to help to solve the problem. It remains clear that purely unilateral emissions reductions by either China or the United States would not be in the domestic self-interest of either China or the United States. ${ }^{10}$ The reason is that such unilateral reductions would impose significant domestic costs and, by themselves, would be unlikely to produce significant domestic benefits. By contrast, the principal victims of climate change, above all in Africa and India, ${ }^{11}$ are not the principal contributors; their own efforts at emissions reduction will do nothing (in the context of Africa) and close to nothing (in the context of India) about the problem.

In two respects, the situation of China is different from that of the United States, in a way that might well make the world's leading emitter even less likely to favor expensive restrictions than the world's second-leading emitter. ${ }^{12}$ First, China is relatively poor, and a relatively poor nation might not be so willing to spend a great deal of money to protect the world, or itself, from harms that will be most severe a number of decades from now. Second, China's per capita emissions remain well below those of the United States, and China has suggested, not implausibly, that a nation with relatively low per capita emissions should not be treated the same as a nation with very high per capita emissions. $^{13}$

Despite these differences, an assessment of the costs and benefits of aggressive emissions reductions has played a significant role in both nations' relative indifference to the problem of climate change. If the world stands to gain from such reductions and if China and the United States do not, the standard response is simple: The world should

\footnotetext{
${ }^{9}$ For a recent study, suggesting significant losses for a large part of the United States, see Peter Frumhoff et al., Confronting Climate Change in the U.S. Northeast (July 2007), available at http://www.climatechoices.org/assets/documents/climatechoices/confronting-climate-change-in-the-u-snortheast.pdf

${ }^{10}$ The qualification, discussed below, is that if unilateral action initiates action by others, the domestic calculation will shift.

${ }^{11}$ See, e,.g., Nordhaus and Boyer, supra note, at 91.

${ }^{12}$ For China's refusal to accept emissions limitations, see http://pubs.bna.com/ip/BNA/IER.NSF/0090432fd78725cb85256b57005b95c9/2099c01aa4134c648525731 500058232?OpenDocument

${ }^{13}$ See National Development and Reform Commission, People's Republic of China, China's National Climate Change Programme 58 (June 2007).
} 
compensate China and the United States for their participation. ${ }^{14}$ In the context of ozonedepleting chemicals, a solution of this kind was implemented for developing countries. ${ }^{15}$ For China, we might well expect a similar solution in the context of climate change. ${ }^{16}$ To say the least, there are both normative and pragmatic problems with proposing that the world pay the United States to reduce its emissions, and those problems might well provide decisive. But the normative issues turn out to be complex and difficult.

My major goals here are simply to explain the complex climate change incentives of the United States and China, to connect those incentives to the current stalemate, and to offer some broader lessons about the favorable and unfavorable conditions for an international agreement to control climate change (and other international problems). But I also mean to provide an account of how the stalemate might be broken. If the United States and China do conclude that they have a great deal to gain from an international agreement, the current situation will shift. Perhaps previous or current perceptions of domestic costs and benefits are biased or erroneous ${ }^{17}$; perhaps they omit important variables. $^{18}$ If the effort to reconsider domestic benefits and costs fails, the best alternative is to convince either or both nations that they have a moral obligation to act to protect those nations that are most vulnerable. There is a strong argument that the United States, in particular, should scale back its emissions in order to reduce threats to people who are both poor and at grave risk. ${ }^{19}$ We shall also see that notwithstanding what I have

\footnotetext{
${ }^{14}$ See Scott Barrett, Environment \& Statecraft 346-49 (2004); seee the general treatment of the "Side Payments Game” in id. at 335-51.

${ }^{15}$ See below.

${ }^{16}$ See Stewart and Wiener, supra note, at 15.

${ }^{17}$ For findings of high costs, see Frumhoff et al., supra note. Frumhoff et al. argue for what they call the "3 percent solution," in the form of annual emissions reduction of 3 percent; but they do not show, or contend, that by itself, this step would produce domestic benefits in excess of costs. Their hope is instead that steps of this kind might be part of, and help spur, international action.

${ }^{18}$ On omitted variables, Bryan K. Mignone, The National Security Dividend of Global Carbon Mitigation (2007), available at http://www.aei-brookings.org/publications/abstract.php?pid=1200; Wayne Hsiung and Cass R. Sunstein, Climate Change and Animals, U Pa L Rev (forthcoming 2007). For an important discussion of uncertainty and catastrophe, see Martin Weitzman, Structural Uncertainty and the Value of a Statistical Life in the Economics of Catastrophic Climate Change (2007), available at http://www.aei-brookings.org/publications/abstract.php?pid=1196

For a general account of climate change that emphasizes harmful effects on many nations, see Stern Review, supra note, and in particular the discussion of extreme events and their consequences, see, e.g., id. at 149-154. The Stern Review does not, however, contend that aggressive controls would survive domestic cost-benefit analysis for the United States or for China.

${ }^{19}$ An alternative of course is for the United States to assist with adaptation, rather than to reduce its own emissions rate. On some of the issues involved in mitigation and adaptation, see Stern Review, supra note, at 622-38; Indur Goklany, The Improving State of the World (2006).
} 
said here, unilateral action by the United States might well turn out to be feasible, through some combination of confusion, hope, and a sense of moral responsibility. And if the United States does act aggressively on its own, China might ultimately be prepared to act as well.

\section{The Mismatch between the Large Emitters and Nations at Most Serious Risk}

My goal in this section is to outline some projections about the anticipated effects of both climate change and greenhouse gas emission reductions. An important qualification is necessary at the outset. To say the least, both the science and the economics are changing, disputed, and based on contentious assumptions, for which small changes make large differences; indeed, that shall be one of my central themes here. The purpose is not to set out uncontroversial point estimates, or to suggest that the particular numbers should be taken to be authoritative. But nations are influenced by a perception of domestic costs and benefits, ${ }^{20}$ and to the extent that the world's leading emitters believe that the domestic costs of emissions controls would be high, and the benefits relatively low, their actions will necessarily be affected.

\section{A. Favorable and Unfavorable Conditions}

It is tempting to see international environmental problems as prisoner's dilemmas, in which nations have no adequate incentive to reduce their harmful emissions on their own, but in which all nations would benefit from an enforceable agreement, requiring reductions on the part of all. ${ }^{21}$ In situations of this kind, nations gain from coercion to which they mutually agree. At first glance, climate change might seem to present a problem of this kind. But as we shall see, the actual picture is far more complex, and the conditions that have faced the world, in connection with the two leading environmental problems of the last decades, do not fit the model of the prisoner's dilemma at all.

1. Favorable conditions. In the environmental domain, a logical precondition for a

\footnotetext{
${ }^{20}$ China has refused to agree to emissions limitations on the implausible ground that it does not know its emissions. It is much more reasonable to think that China does not want to spend high costs for uncertain benefits. See China "Will Not Accept" Emisisons Limits (July 2007), available at http://pubs.bna.com/ip/BNA/IER.NSF/0090432fd78725cb85256b57005b95c9/2099c01aa4134c648525731 500058232?OpenDocument

${ }^{21}$ For excellent general treatments, see Scott Barrett, Environment and Statecraft: The Strategy of Environmental Treaty-Making (2004); Todd Sandler, Global Collective Action (2004).
} 
successful international agreement is simple to describe: The major contributors to the problem must have a great deal to lose if the problem remains unsolved. The situation is more favorable still if two specific conditions are met: (a) from the standpoint of major contributors, unilateral action to reduce emissions is desirable and (b) the major contributors would gain even more from an international agreement than from unilateral action. Under those conditions, the major contributors will both act on their own and work aggressively to ensure that other nations act as well. And in that event, the likelihood of an international agreement will be exceedingly high.

In the context of the problem of ozone depletion, both of the two conditions were met. $^{22}$ An agreement was possible in large part because the relevant officials in the United States, the leading contributor, were entirely aware that the nation's own citizens were at grave risk from depletion of the ozone layer. ${ }^{23}$ Indeed, the United States had so much to lose from depletion of the ozone layer that purely unilateral action would produce benefits far in excess of the costs. ${ }^{24}$ (Several other nations also concluded that unilateral action was justified. ${ }^{25}$ ) In addition, the United States had a great deal to gain from international action; emissions from other nations would eventually impose significant harms on American citizens. ${ }^{26}$

Consider the contemporaneous account, by the Environmental Protection Agency, of the costs and benefits of the Montreal Protocol ${ }^{27}$ :

Table 1

Costs and Benefits of Montreal Protocol to the United States (in billions of 1985 dollars):

\begin{tabular}{|l|c|c|c|}
\hline & No controls & Montreal Protocol & $\begin{array}{c}\text { Unilateral Implementation of Montreal } \\
\text { Protocol by the United States }\end{array}$ \\
\hline Benefits & - & 3,575 & 1,363 \\
\hline Costs & - & 21 & 21 \\
\hline Net benefits & - & 3,554 & 1,352 \\
\hline
\end{tabular}

\footnotetext{
${ }^{22}$ See Barrett, supra note; Cass R. Sunstein, Of Montreal and Kyoto: A Tale of Two Protocols, 31 Harv Env L Rev 1 (2007).

23 See Barrett, supra note; Richard Benedict, Ozone Diplomacy (2000).

${ }^{24}$ See Barrett, supra note, at 228.

25 James Murdoch and Todd Sandler, The Voluntary Provision of a Public Good: The Case of Reduced CFC Emissions and the Montreal Protocol, 63 J Public Economics 331 (1997).

${ }^{26}$ Barrett, supra note, at 227-29.

27 See id. at 228.
} 
These figures were generated from a projection of over five million skin cancer deaths by 2165, together with over twenty-five million cataract cases by that yearfigures that would be cut to 200,000 and two million, respectively, by a 50\% CFC reduction. ${ }^{28}$ What is most noteworthy here is that the costs of significant emissions controls were dwarfed by the benefits of unilateral action. What is almost equally noteworthy is that the benefits to the United States would be nearly tripled by a worldwide agreement.

With these figures before the White House, President Reagan — not known as an environmental president—pushed aggressively for the Montreal Protocol. ${ }^{29}$ Facing strong pressure from the world's leading contributor, other countries were willing and able to agree. ${ }^{30}$ Indeed, a near-unanimous Senate asked President Reagan to seek aggressive controls well before the agreement was negotiated, ${ }^{31}$ and later the Senate unanimously ratified the Montreal Protocol on the basis of the legislators' general awareness of the underlying facts. ${ }^{32}$

2. Unfavorable conditions. We can also imagine a situation at the opposite pole, in which the major contributors to an environmental problem (believe that they) would not much suffer from it, and hence would lose from an international agreement on balance, while those who are most vulnerable contribute essentially nothing to the problem. In the most poignant version of this situation, an international agreement would produce overall welfare gains, because the most vulnerable nations stand to lose more from the problem than the contributors would lose from reducing it. This scenario is poignant because the conditions appear to suggest that an agreement that would be in the world's interest will be difficult to achieve, because those who are in the best position to solve the problem will be most reluctant to do so (at least without side-payments).

Under the assumptions given, unilateral action by the major contributors would make no sense, certainly not from the standpoint of national self-interest. Worse still, the

\footnotetext{
${ }^{28}$ See Stephen J. DeCanio, Economic Analysis, Environmental Policy, and Intergenerational Justice in the Reagan Administration, 3 International Environmental Agreements: Politics, Law and Economics 299, 302 (2003). See id. for more information on how these harms were turned into monetary equivalents and in particular for discussion of the choice of a low discount rate

${ }^{29}$ See Edward Parson, Protecting the Ozone Layer 240 (2005); Benedict, supra note.

${ }^{30}$ See Barrett, supra note.

${ }^{31}$ Benedick, supra note, at 61-62.

${ }^{32}$ See http://www.findarticles.com/p/articles/mi_m1079/is_n2135_v88/ai_6495606 (signing statement by President Reagan, emphasizing Senate unanimity).
} 
major contributors would also be expected to be highly resistant to an international agreement, because emissions limitations would produce small domestic benefits and high domestic costs. ${ }^{33}$ In the extreme case, an international solution might not be feasible, at least if the principal contributors are both self-interested and powerful, and if sidepayments are not forthcoming. If those contributors would gain nothing and lose much from emissions reductions, they have no incentive to act even if all or most other nations act as well.

The American refusal to ratify the Kyoto Protocol had everything to do with a perception of this general kind. ${ }^{34}$ The United States would have had to spend far more than other nations to comply with the stated commitments ${ }^{35}$; on one estimate, the American share of total costs could be as high as 80 percent. $^{36}$ And because the developing countries refused to accept emissions limitations, the United States had relatively little to gain. On the numbers as they were generated at the time, the United States would have to spend over $\$ 300$ billion to comply with the requirements of the Kyoto Protocol, and the monetized benefits, for the United States, would be about four percent of that amount. ${ }^{37} \mathrm{~A}$ key reason is that the Kyoto Protocol did not impose emissions limitations on developing nations, and for that reason, it would make a small dent in warming by 2100 even with full compliance. ${ }^{38}$

Consider the following projection of the costs and benefits of the Kyoto Protocol for the United States alone - a projection designed not to offer an undisputed point estimate, but to describe what prominent analysts suggested when the United States was making its key decisions ${ }^{39}$ :

\footnotetext{
${ }^{33}$ A qualification, discussed below, is this: If the contributor nation might benefit from technological innovations, which could be sold elsewhere, it might be willing to support limits even if it is not greatly at risk.

${ }^{34}$ See http://www.whitehouse.gov/news/releases/2001/03/20010314.html (2001 letter from President Bush outlining his views on climate change policy)

${ }^{35}$ See Nordhaus and Boyer, supra note.

${ }^{36}$ Stewart and Wiener, supra note, at 10.

${ }^{37}$ See Nordhaus and Boyer, supra note. Updated and much larger estimates of the cost of Kyoto, for the United States, are presented in Nordhaus, supra note.

${ }^{38}$ See Nordhaus and Boyer, supra note (finding a 0.03 C decrease in anticipated warming by 2100); Bjorn Lomborg, Cool It (2007) (finding a $0.3 \mathrm{~F}$ decrease in anticipated warming by 2100).

${ }^{39}$ Compiled on the basis of Nordhaus and Boyer, supra note, at 156-67.
} 
Table 2

Costs and Benefits of Kyoto Protocol for the United States (in billions of 2000 dollars):

\begin{tabular}{|l|c|c|c|}
\hline & No Controls & Kyoto Protocol & $\begin{array}{c}\text { Unilateral Action to Comply } \\
\text { with Kyoto Protocol }\end{array}$ \\
\hline Benefits & - & 12 & $0^{40}$ \\
\hline Costs & - & 325 & 325 \\
\hline Net Benefits & - & -313 & -325 \\
\hline
\end{tabular}

From these figures, it should be clear that if the United States acted on its own, or acted with a small subset of emitters, the benefits from greenhouse gas reductions would be quite small. Broad participation is necessary to make any real dent in the problem. ${ }^{41}$ In 1997 a unanimous Senate, apparently aware of this point, adopted Senate Resolution 98, which asked President Clinton not to agree to limits on greenhouse gas emissions if the agreement would injure the economic interests of the United States or if it would "mandate[] new specific scheduled commitments to limit or reduce greenhouse gas emissions for Developing Country Parties within the same compliance period” as for the United States. ${ }^{42}$ Indeed, the unanimous Senate concluded that any "exemption for Developing Country Parties is inconsistent with the need for global action on climate change and is environmentally flawed" and indicated that it "strongly believed" that the proposals under consideration "could result in serious harm to the United States economy, including significant job loss, trade disadvantages, increased energy and consumer costs, or any combination thereof."43

Because the developing nations were not going to agree to emissions limitations, this request effectively ensured that the United States would not ratify the resulting agreement. ${ }^{44}$ And after the negotiation, the Senate unanimously refused to ratify it, on the basis of a perception that the United States had far more to lose than to gain. ${ }^{45}$ With meaningful participation by the developing nations, those benefits would have significantly increased, ${ }^{46}$ and the United States would have been more receptive. But to say this is to get ahead of the story.

\footnotetext{
${ }^{40}$ This estimate is of course rough. It is based on the assumption that unilateral action would have no significant effect in reducing the harms associated with climate change for the United States.

${ }^{41}$ See the detailed treatment in Nordhaus, supra note.

${ }^{42} \mathrm{http}: / /$ www.opic.gov/GeneralOPIC/senateresolution98.htm

${ }^{43}$ Id.

${ }^{44}$ See Sunstein, supra note.

${ }^{45} \mathrm{Id}$.

${ }^{46}$ See Olmstead and Stavins, supra note.
} 
There were large efforts, by the United States above all, to convince China and other developing nations to agree to emissions limitations in the Kyoto Protocol. ${ }^{47}$ These efforts were unsuccessful. China did ratify the agreement, to considerable international fanfare, ${ }^{48}$ but its ratification was essentially meaningless, because the protocol imposes no obligations on China at all. In refusing to agree to emissions limitations, China made an array of equitable arguments, emphasizing its relative poverty, its relatively low per capita emissions, and the fact that the existing "stock" of greenhouse gas emissions is a product of the industrialized nations, which benefited from those emissions. ${ }^{49}$ But there is no question that China was greatly influenced by two perceptions: it would not greatly benefit from emissions reductions, and those reductions would cost a great deal. At least as much as the United States, China was affected by a purely domestic cost-benefit analysis, which appeared to argue strongly against acceptance of international emissions reduction requirements. ${ }^{50}$

Now let us turn to the contemporary situation.

\section{B. Climate Change Losers}

Which nations are expected to suffer most from climate change? Which nations have least to lose? Of course the precise figures are greatly disputed, and estimates are constantly changing ${ }^{51}$; any effort to specify the damage will depend on controversial scientific or economic assumptions. But it is generally agreed that the poorest nations will be the biggest losers by far. ${ }^{52}$ The wealthy nations, including the United States, are in a much better position for three independent reasons. ${ }^{53}$ First, they have much more in the way of adaptive capacity. Second, a smaller percentage of their economy depends on agriculture, a sector that is highly vulnerable to climate change. Third, the wealthy

\footnotetext{
${ }^{47}$ See Robert Pervical et al., Environmental Regulation 1134 (3d ed. 2000) (“The U.S. effort to obtain some expression by the largest developing nations of their willingness to constrain their emissions at some future time was completely unsuccessful.”).

${ }^{48}$ See Benedick, supra note, at 196.

${ }^{49}$ See Jiahua Pan, Common But Differentiated Commitments: A Practical Approach to Engaging Large Developing Emitters Under L20 3 (Sept. 20-21, 2004) (available with author) (referring to cumulative emissions but emphasizing period of 1990-2000, when consequences were widely known).

${ }^{50}$ See id.

${ }^{51}$ For various accounts, see Stern, supra note; Fourth Assessment Report of the Intergovernmental Panel on Climate Change, Working Group I, available at http://www.ipcc.ch/; Frumhoff et al., supra note.

${ }^{52}$ Stern, supra note, at 139; Richard Tol, Estimates of the Damage Costs of Climate Change, 21 Environmental and Resource Economics 135 (2002).

${ }^{53}$ Stern, supra note, at 139.
} 
nations are generally in the cooler, higher latitudes, which also decreases their vulnerability. ${ }^{54}$ These points should not be taken to suggest that the developed world has nothing at stake; some projections suggest large losses. ${ }^{55}$ But all accounts suggest that wealthy nations are in a far better position to deal with increased temperatures. China is not wealthy, but it is hardly among the nations most at risk, and indeed "many forecasts of the impacts of global warming suggest that China would on balance benefit from a warmer world."56

In its latest report, the Intergovernmental Panel on Climate Change projected a "best estimate" of warming of between $1.8 \mathrm{C}$ and $4.0 \mathrm{C}$ by $2100 .^{57}$ For essentially all nations, the anticipated damage would of course be far higher with an increase of $4.0 \mathrm{C}$ than with an increase of $1.8 \mathrm{C}$. To get a handle on the problem, let us assume that warming will be $2.5 \mathrm{C}$, and consider a prominent estimate of how the harms are likely to vary across nations and regions ${ }^{58}$ :

Table 3

Damages of a 2.5 C Degree Warming as a Percentage of GDP

\begin{tabular}{|l|l|}
\hline India & 4.93 \\
\hline Africa & 3.91 \\
\hline OECD Europe & 2.83 \\
\hline High income OPEC & 1.95 \\
\hline Eastern Europe & 0.71 \\
\hline Japan & 0.50 \\
\hline United States & 0.45 \\
\hline China & 0.22 \\
\hline Russia & -0.65 \\
\hline
\end{tabular}

On these estimates, it is readily apparent that some nations are far more vulnerable than others. ${ }^{59}$ For current purposes, the most noteworthy parts of the list are

${ }^{54} \mathrm{Id}$.

${ }^{55}$ See id.; Frumhoff et al., supra note.

${ }^{56}$ See Stewart and Wiener, supra note, at 15.

${ }^{57}$ See Intergovernmental Panel on Climate Change, supra note; Nordhaus, supra note.

${ }^{58}$ Nordhaus and Boyer, supra note.

${ }^{59}$ Tol, supra note, is in general accord. William Cline, Climate Change, in Global Problems, Global Solutions 13 (Bjorn Lomborg ed. 2004), and Frank Ackerman and Ian Finlayson, The Economics of Inaction on Climate Change: A Sensitivity Analysis (forthcoming 2007), offer a picture of more serious monetized damage from climate change. 
the bottom and the top, respectively. The United States, China, and Russia are expected to lose relatively little from $2.5 \mathrm{C}$ warming; indeed, Russia is expected to gain. By contrast, India and Africa are anticipated to be massive losers. India is expected to experience devastating losses in terms of both health and agriculture. Here too there is a great deal of uncertainty, in part because of the difficulty of projecting future economic growth and adaptation, and any point estimates must be taken with many grains of salt. But in terms of health alone, India has been projected to lose 3,600,000 years of life because of climate-related diseases, with 769,000 years of life lost from malaria alone. ${ }^{60}$ For Africa, the major problem involves health, with a massive anticipated increase in climate-related diseases. ${ }^{61}$ Sub-Saharan Africa has been projected to lose 26,677,000 years of life because of climate-related diseases, with 24,385,000 coming from malaria. ${ }^{62}$

To be sure, the evidence here is somewhat dated as well as controversial, but every existing estimate of the costs of climate change confirms that Africa and India are particularly vulnerable. ${ }^{63}$ While other studies emphasize that China and the United States have significant amounts to lose, ${ }^{64}$ no numerical estimate suggests that the two nations are unusually vulnerable in terms of either agriculture or health.

It seems clear that the United States faces more limited threats on all relevant dimensions. ${ }^{65}$ On some estimates, American agriculture will actually be a net winner as a result of climate change. ${ }^{66}$ Consider one study of the long-run effects of climate change on a range of economic variables in the United States. ${ }^{67}$ The study offers both optimistic projections, including a high level of adaptation and low warming, and pessimistic

\footnotetext{
${ }^{60}$ Nordhaus and Boyer, supra note, at 81.

${ }^{61}$ Id.

${ }^{62} \mathrm{Id}$.

${ }^{63}$ See, e.g., Tol, supra note; Stern, supra note.

${ }^{64}$ See, e.g., Frumhoff et al., supra (cataloguing losses in Northeastern United States); Stern, supra note (broadly outlining losses to developed world and also to China).

${ }^{65}$ But see Frumhoff et al., supra note, at 67-80 (emphasizing adverse effects on agriculture); id at 91-104 (emphasizing adverse effects on health).

${ }^{66}$ See Olivier Deschenes and Michael Greenstone, The Economic Impacts of Climate Change: Evidence from Agricultural Output and Random Fluctuations of Weather (2006), available at http://www.aeibrookings.org/publications/abstract.php?pid=1031; compare the suggestion in Nordhaus and Boyer, supra note, at 97, that "the economic impact of gradual climate change (that is, omitting catastrophic outcomes) is close to zero for a moderate (2.5 degree C) global warming." Note that this conclusion does not come to terms with the economic effects on the United States that would come from the very fact of serious economic harms in other nations.

${ }^{67}$ See Dale Jorgenson et al., U.S. Market Consequences of Global Climate Change (2004), available at http://www.pewclimate.org/global-warming-in-depth/all_reports/marketconsequences; see also the brief summary in Stern, supra note, at 147-148.
} 
projections, involving little adaptation and higher warming. For $3 \mathrm{C}$ warming, the most optimistic case projects an increase of one percent in GDP; the benefits are highest at $2 \mathrm{C}$ warming and decline from 3.5 C. The most pessimistic case projects losses of 1.2 percent of GDP at 3 C. It should be clear that if the United States anticipates that it is not likely to lose a great deal, on net, from climate change, its incentive to participate in an international agreement will not be very high. And if the United States anticipates a "worst case," at 3 C warming, of 1.2 percent loss in GDP, the incentive is relatively weak. Existing interest in unilateral action, within the United States, presents several puzzles in this light; I will return to those puzzles below.

Like Russia, China has been projected to benefit in terms of agriculture, and while it will suffer health losses, they have been estimated to be at least relatively modest, far below those expected in Africa and India. ${ }^{68}$ As I have said, some accounts have found that China would gain, on net, from warming. ${ }^{69}$ On one projection, China will lose 603,000 years of life from climate-related causes, and just 8000 from malaria. ${ }^{70}$ The loss of 600,000 years of life is highly significant, but it is far below the corresponding losses for the most threatened nations. To the extent that the losses are not overwhelming, we might expect that China would be unlikely to be particularly interested in reducing greenhouse gas emissions, at least on these figures; thus far, the nation's behavior is consistent with that prediction. Note in this regard the striking fact that the citizens of China and the United States are less concerned about climate change than are the citizens of Japan, France, Spain, India, Britain, and Germany. ${ }^{71}$

\section{Emitting Nations}

But how much do nations stand to lose from reductions? It is clear that the costs of the Kyoto Protocol were anticipated to be especially high for the United States; indeed, the costs for the United States would be much greater than the corresponding costs for any other signatory nation, and probably for all other signatory nations combined. ${ }^{72}$ Unfortunately, we do not have recent estimates of the costs of emissions reductions for

\footnotetext{
${ }^{68}$ See Nordhaus and Boyer, supra note, at 81.

${ }^{69}$ Stewart and Wiener, supra note, at 15.

${ }^{70}$ Nordhaus and Boyer, supra note, at 81.

${ }^{71}$ See Doing It Their Way, The Economist 22 (Sept. 9-16, 2006).

72 See Nordhaus and Boyer, supra note, at 159; Nordhaus, supra note 1.
} 
various nations. As a proxy for those costs, it makes sense to begin by seeing which nations are principal contributors to the problem. If an international agreement is struck, the largest contributors are likely to have to bear the highest costs. Suppose, for example, that a worldwide carbon tax is imposed, beginning at a cost of $\$ 27$ per metric ton. ${ }^{73}$ It stands to reason that the largest carbon emitters would face the most significant burdens. (I will qualify this point below. ${ }^{74}$ )

It is important and true that a genuinely global emissions trading program would reduce those burdens. If American companies can buy emissions credits from (say) India, they should be able to comply with international obligations far more cheaply than if they had to make reductions on their own. ${ }^{75}$ But even with global trading, large emitting countries would bear large financial burdens. ${ }^{76}$

For democratic governments, this point evidently matters. Political leaders would suffer serious electoral retribution if they proposed or adopted measures that would produce significant increases in the cost of gasoline and electricity. Consider, for example, a study by the Department of Energy, projecting that the Kyoto Protocol would produce substantial gasoline price increases of 52 cents per gallon, and 20 percent to 86 percent increases in the price of electricity by $2010 .^{77}$ If emissions reductions increased, or were expected to increase, gasoline prices by any significant amount, public objections would likely be vigorous, certainly to the extent that the price increases were understood as an effort to reduce a speculative threat in the distant future. Americans are now concerned about the problem of climate change and support the Kyoto Protocol, but they are not (yet?) willing to bear significant costs in the form of increased gasoline or energy prices. ${ }^{78}$ Nondemocratic leaders, such as those in China, have complex incentives of their own. ${ }^{79}$ The only suggestion is that if significant emissions controls imposed large and

\footnotetext{
${ }^{73}$ See Nordhaus, supra note 1 , at 11 .

${ }^{74}$ See the discussion below of technological innovation at DuPont, significantly driving down the costs of substitutes for CFCs, and thus making it far less expensive for the United States, the world's leading contributor, to comply with strict emissions limits.

${ }^{75}$ See Nordhaus and Boyer, supra note.

${ }^{76}$ Id.

77 George Pring, The United States Perspective, in Kyoto: From Principles to Practice 185, 194 (Peter Cameron and Donald Zillman eds. 2001).

${ }^{78}$ See the catalogue in Cass R. Sunstein, Worst-Case Scenarios (forthcoming 2007).

79 See China "Will Not Accept" Emisisons Limits (July 2007), available at http://pubs.bna.com/ip/BNA/IER.NSF/0090432fd78725cb85256b57005b95c9/2099c01aa4134c648525731 500058232?OpenDocument
} 
palpable costs on the United States, officials would have to work very hard to convince the public that the costs were justified - and perhaps that the United States is playing its part in a genuine international effort, rather than as first-movers facing general intransigence from other nations.

To get a handle on the problem, consider the following table, offering a snapshot of global contributors in 2003 and 2004 (limited to carbon dioxide, the leading greenhouse gas ${ }^{80}$ :

Table 4

\begin{tabular}{|c|c|c|}
\hline \multicolumn{3}{|c|}{ Share of Global Emissions } \\
\hline & $\mathbf{2 0 0 3}$ & $\mathbf{2 0 0 4}$ \\
\hline United States & $22.7 \%$ & $22.0 \%$ \\
\hline OECD Europe & $16.9 \%$ & $16.3 \%$ \\
\hline China & $15.3 \%$ & $17.5 \%$ \\
\hline India & $4.1 \%$ & $4.1 \%$ \\
\hline Japan & $4.9 \%$ & $4.7 \%$ \\
\hline Africa & $3.5 \%$ & $3.4 \%$ \\
\hline Russia & $4.2 \%$ & $4.2 \%$ \\
\hline
\end{tabular}

As early as 2004, then, the United States and China emerged as the top emitters, accounting for nearly $40 \%$ of the world's total. ${ }^{81}$ If our goal is to project the costs of emissions reductions in the future, of course, this chart does not tell us nearly enough; it is necessary to understand the trends over time. The most significant contributors in the past may not be the most significant contributors in the future. Existing projections suggest that the largest contributors are likely to continue to qualify as such — but that major shifts will occur, above all with explosive emissions growth in China and India, and emissions reductions in Russia and Germany.

\footnotetext{
${ }^{80}$ United States Energy Information Administration, International Energy Outlook 2007 available at www.eia.doe.gov/oiaf/ieo/index.html.

${ }^{81}$ See the call, in 2003, for a “United States-China Strategy,” in Stewart and Wiener, supra note, at 10.
} 
Table 5

Carbon Dioxide Emissions Changes, 1990-2004 ${ }^{82}$

\begin{tabular}{|l|r|}
\hline \multicolumn{1}{|c|}{ Countries } & 1990-2004 \\
\hline China & $108.3 \%$ \\
\hline United States & $19.8 \%$ \\
\hline India & $87.5 \%$ \\
\hline South Korea & $104.6 \%$ \\
\hline Iran & $110.7 \%$ \\
\hline Indonesia & $137.7 \%$ \\
\hline Saudi Arabia & $85.6 \%$ \\
\hline Brazil & $67.8 \%$ \\
\hline Spain & $59.0 \%$ \\
\hline Pakistan & $96.6 \%$ \\
\hline Poland & $-15.3 \%$ \\
\hline EU-25 & $1.6 \%$ \\
\hline Germany & $-12.2 \%$ \\
\hline Ukraine & $-47.1 \%$ \\
\hline Russia & $-24.8 \%$ \\
\hline
\end{tabular}

Here we can see rapid emissions increases in some places, above all China, South Korea, Iran, Indonesian, Saudi Arabia, and Pakistan. With these trend lines, we can project changes by 2030. At that time, the developing world is expected to contribute no less than $55 \%$ of total emissions, with $45 \%$ coming from developed nations. ${ }^{83}$ At that time, the United States is expected to be well below China. Consider the figures for anticipated growth:

Table 6

Average Annual Projected Changes in CO2 Emissions 2004-2030 84

\begin{tabular}{|l|c|c|c|}
\hline Country & Reference Case & $\begin{array}{c}\text { High Economic } \\
\text { Growth Case }\end{array}$ & $\begin{array}{c}\text { Low Economic } \\
\text { Growth Case }\end{array}$ \\
\hline India & $2.6 \%$ & $3 \%$ & $2.2 \%$ \\
\hline Mexico & $2.3 \%$ & $2.7 \%$ & $1.9 \%$ \\
\hline China & $3.4 \%$ & $3.8 \%$ & $3.0 \%$ \\
\hline Brazil & $2.3 \%$ & $2.8 \%$ & $1.7 \%$ \\
\hline South Korea & $1.3 \%$ & $1.8 \%$ & $0.7 \%$ \\
\hline OECD Europe & $0.3 \%$ & $0.6 \%$ & $-0.1 \%$ \\
\hline United States & $1.1 \%$ & $1.5 \%$ & $0.7 \%$ \\
\hline World & $1.8 \%$ & $2.2 \%$ & $1.4 \%$ \\
\hline
\end{tabular}

${ }^{82}$ Emissions of CO2 from energy-related sources only. See International Energy Agency, CO2 Emissions From Fuel Combustion 1971-2004: 2006 Edition, pp. II.4-II.7

${ }^{83}$ Own calculations based on US IEA, supra note.

${ }^{84}$ Id. 
Table 7

Percentage Change in CO2 Emissions Projected 2004-2030 ${ }^{85}$

\begin{tabular}{|l|c|c|c|}
\hline Country & Reference Case & $\begin{array}{c}\text { High Economic } \\
\text { Growth Case }\end{array}$ & $\begin{array}{c}\text { Low Economic } \\
\text { Growth Case }\end{array}$ \\
\hline India & $94 \%$ & $116 \%$ & $74 \%$ \\
\hline Mexico & $82 \%$ & $102 \%$ & $63 \%$ \\
\hline China & $139 \%$ & $167 \%$ & $115 \%$ \\
\hline Brazil & $79 \%$ & $104 \%$ & $57 \%$ \\
\hline South Korea & $39 \%$ & $60 \%$ & $21 \%$ \\
\hline OECD Europe & $7 \%$ & $17 \%$ & $-3 \%$ \\
\hline United States & $34 \%$ & $47 \%$ & $21 \%$ \\
\hline World & $59 \%$ & $77 \%$ & $43 \%$ \\
\hline
\end{tabular}

There are several key points here. China's growth rate is more than double the world's average. While China and the United States had essentially the same level of aggregate emissions in 2007, China's emissions are projected to grow over three times as rapidly as those of the United States. And on this projection, China's growth rate will dwarf the corresponding rates of India, Mexico, and South Korea. In terms of aggregate contributions, these changes mean that there will be significant shifts among contributors:

Table 8

Relative Contributions of Annual Carbon Dioxide Emissions by Country/Region (Approximate \% of Worldwide Emissions) ${ }^{86}$

\begin{tabular}{|c|c|c|c|c|c|c|c|c|}
\hline & $\mathbf{1 9 9 0}$ & $\mathbf{2 0 0 3}$ & $\mathbf{2 0 0 4}$ & $\mathbf{2 0 1 0}$ & $\mathbf{2 0 1 5}$ & $\mathbf{2 0 2 0}$ & $\mathbf{2 0 2 5}$ & $\mathbf{2 0 3 0}$ \\
\hline United States & $23.5 \%$ & $22.7 \%$ & $22.0 \%$ & $20.1 \%$ & $19.4 \%$ & $18.8 \%$ & $18.7 \%$ & $18.5 \%$ \\
\hline OECD Europe & $19.3 \%$ & $16.9 \%$ & $16.3 \%$ & $14.6 \%$ & $13.4 \%$ & $12.4 \%$ & $11.6 \%$ & $10.9 \%$ \\
\hline China & $10.5 \%$ & $15.3 \%$ & $17.5 \%$ & $21.1 \%$ & $22.4 \%$ & $23.9 \%$ & $25.0 \%$ & $26.2 \%$ \\
\hline India & $2.7 \%$ & $4.1 \%$ & $4.1 \%$ & $4.2 \%$ & $4.4 \%$ & $4.7 \%$ & $4.9 \%$ & $5.0 \%$ \\
\hline Japan & $4.8 \%$ & $4.9 \%$ & $4.7 \%$ & $4.1 \%$ & $3.8 \%$ & $3.5 \%$ & $3.3 \%$ & $3.0 \%$ \\
\hline Africa & $3.1 \%$ & $3.5 \%$ & $3.4 \%$ & $3.7 \%$ & $3.8 \%$ & $3.9 \%$ & $3.9 \%$ & $3.9 \%$ \\
\hline
\end{tabular}

This projection, suggesting that by 2030 China's emissions will be $50 \%$ higher than those of the United States, is fairly recent; but with explosive emissions growth in China, it is already out of date. China is now believed to have passed the United States in $\mathrm{CO}_{2}$ emissions as early as 2007 and possibly before. ${ }^{87}$

\footnotetext{
${ }^{85}$ Own calculations based on id.

${ }^{86}$ Id.

${ }^{87}$ See Audra Ang, China Overtakes U.S. as Top CO2 Emitter. Associated Press Online, June 21, 2007
} 


\section{The Problem}

We can now identify a real obstacle to an international agreement to control greenhouse gases. The United States and China are the largest emitters, and at least on prominent projections, they also stand to lose relatively less from climate change. In terms of their own domestic self-interest, these projections weaken the argument for stringent controls. The nations of Africa stand to lose a great deal, but they are trivial greenhouse gas emitters; they have every reason to favor aggressive reductions but cannot even dent the problem on their own. India may be even more vulnerable, and its contribution, while rapidly growing and far from trivial, is comparatively modest. India too should favor aggressive reductions, but its own unilateral steps would essentially contribute nothing to solving the problem.

For complex reasons, the United States might nonetheless prove willing to undertake significant reductions, but the incentive problem is especially serious for China. A poor nation is unlikely to spend a great deal to reduce a danger that may not materialize for decades and whose magnitude, at least for China, remains at least to some degree speculative. With so many economic problems to solve, and with a high degree of poverty, climate change may well seem a low priority. ${ }^{88}$ By contrast, a wealthy nation is in a much better position to purchase insurance against the risk of future catastrophe. ${ }^{89}$ For this reason it is reasonable to expect that the United States would be more inclined to take aggressive precautionary steps than China. But it remains true that on prominent projections, the world's leading emitters are similarly situated in the sense that significant emissions reductions would impose high costs for gains that are far lower than those anticipated in (say) India and Africa.

It follows that the current situation is no simple prisoner's dilemma, in which nations lose from unilateral action but gain from enforceable limitations on one another's behavior. Even though an international agreement would be in the world's interest, taking the world as a whole, ${ }^{90}$ neither China or the United States might perceive such an agreement as in their interest, simply because both nations seem to have disproportionately little to lose from climate change and disproportionately much to lose

\footnotetext{
${ }^{88}$ See Lomborg, Cool It, supra note; Global Problems, Global Solutions (Bjorn Lomborg ed. 2004).

${ }^{89}$ On climate change and extreme events, see Stern, supra note, at 149-154.

${ }^{90}$ See Nordhaus, supra note.
} 
from emissions reductions. More precisely, the agreement that is optimal from the standpoint of the world might not be optimal from the standpoint of the United States and China. If the world would do best with a worldwide tax of (say) \$40 per ton of carbon, the United States might do best with a worldwide tax of \$20 per ton of carbon, and China with a worldwide tax of $\$ 10$ per ton of carbon.

Actually the analysis has an additional complexity. Some nations, above all China, might reasonably object that their own contribution is much smaller than the aggregate figures suggest. In assessing relative contributions, we might be interested in cumulative emissions rather than annual emissions. ${ }^{91}$ The overall stock matters, not only the current flow. Here is the relevant data:

Table 9

Cumulative CO2 Emissions, 1850-2002 ${ }^{92}$

\begin{tabular}{|l|c|}
\hline \multicolumn{1}{|c|}{ Countries } & \\
\hline United States & 29.3 \\
\hline EU-25 & 26.5 \\
\hline Russia & 8.1 \\
\hline China & 7.6 \\
\hline Germany & 7.3 \\
\hline United Kingdom & 6.3 \\
\hline Japan & 4.1 \\
\hline France & 2.9 \\
\hline India & 2.2 \\
\hline Ukraine & 2.2 \\
\hline
\end{tabular}

Notice in this regard that for a long period, China's emissions were a small fraction of those of the United States. Even though China's emissions rates have now passed those of the United States, it might well insist that it should not bear the same economic burden as a nation that is responsible for a much larger percentage of aggregate emissions. Perhaps the economic burden should be a product of total contribution to the problem, extending over time.

China might well add that its per capita emissions are far lower than those of the United States. Consider the following table of per capita emissions in 2004:

\footnotetext{
${ }^{91}$ See Jiahua Pan, Common But Differentiated Commitments: A Practical Approach to Engaging Large Developing Emitters Under L20 3 (Sept. 20-21, 2004) (available with author) (referring to cumulative emissions but emphasizing period of 1990-2000, when consequences were widely known).

${ }^{92}$ Keith Baumert et al., Navigating the Numbers 32 (2005).
} 
Table 10

Tons of CO2 Emitted Per Capita in $2004^{93}$

\begin{tabular}{|l|r|}
\hline United States & 19.73 \\
\hline EU-25 & 8.46 \\
\hline Russia & 10.63 \\
\hline China & 3.66 \\
\hline Germany & 10.29 \\
\hline United Kingdom & 8.98 \\
\hline Japan & 9.52 \\
\hline France & 6.22 \\
\hline India & 1.02 \\
\hline Ukraine & 6.42 \\
\hline
\end{tabular}

Notwithstanding its status as the largest emitter on the planet, China's per capita emissions are only one-fifth those of the United States, and they remain well below those of many nations, including Russia, Germany, Japan, France, and Ukraine. Invoking the disparities traced above, China might insist, not implausibly, that per capita emissions are what matter. To see the intuition behind the point, imagine a world with three nations, having populations of one billion, one hundred million, and one million. Imagine too that all three nations have the same level of aggregate greenhouse gas emissions - and that the third nation, with a much higher per capita emissions rate, asks the other two to scale back their emissions by the same rate. The nation with one billion people would quite plausibly say that what matters is the per capita rate, and that it is absurd to think that a nation with one million people should be entitled to have the same aggregate emissions rate as a nation with a billion.

The debate over per capita emissions thus matters to an evaluation of appropriate policy. To be sure, no one doubts that the purely domestic calculus—of costs and benefits-will play a significant role in any nation’s decisions. But fairness judgments, attending to cumulative contributions and to per capita rates, are unlikely to be entirely irrelevant. $^{94}$

\footnotetext{
${ }^{93}$ Energy-related CO2 emissions only. See International Energy Agency, supra note, pp. II.49-II. 51

${ }^{94}$ Pan, supra note.
} 


\section{Solutions?}

If the United States and China are to agree to emissions limitations, a method must be found to overcome their complex incentives. The first method would appeal to self-interest; the second would attempt moral suasion. If general international practice is the guide, the first method is far more likely to work, ${ }^{95}$ but we cannot exclude the possibility that one or both nations might respond to moral arguments.

\section{A. A Puzzle}

There is a puzzle to be underlined at the outset: Notwithstanding what I have said thus far, unilateral action by the United States has attracted considerable support at the national and state levels, and it is fully possible that national emissions limits will be enacted relatively soon. As early as June 22, 2005, a 53-44 majority of the United States Senate approved a "sense of the Senate" resolution to the effect that "Congress should enact a comprehensive and effective national program of mandatory market-based limits and incentives on greenhouse gases that slow, stop and reverse the growth of such emissions . . .."96 A fairly aggressive legislative proposal, from Senators John McCain and Joseph Lieberman in 2003, would have capped greenhouse gas emissions at 2000 levels. The proposal was defeated by a vote of 55-43. ${ }^{97}$ But many prominent members of Congress have supported similar legislation, ${ }^{98}$ and prominent companies, including Duke Energy and Alabama Power, have supported emissions limits. ${ }^{99}$ There seems to be little legislative support for a carbon tax, ${ }^{100}$ but it would not be at all surprising to find some kind of national “cap-and-trade” program in the near future.

Far more has already happened at the state level. In December 2005, the governors of seven states signed a Memorandum of Understanding, designed to create a

\footnotetext{
95 See Robert Keohane, After Hegemony (1984).

${ }^{96}$ Daniel R. Abbasi, Americans and Climate Change 20-23 (2006).

${ }^{97}$ For an overview, see http://commerce.senate.gov/newsroom/printable.cfm?id=214305; for an analysis, see Sergey Paltsev et al., Emissions Trading to Reduce Greenhouse Gases in the United States: The McCain-Lieberman Proposal, available at http://web.mit.edu/globalchange/www/reports.html.

98 For a list of proposals, see http://www.earthscape.org/l2/ES17454/index.html; for an illuminating comparison, see http://www.pewclimate.org/policy_center/analyses/csia_ceia_comparison.cfm

99 See Lawmakers Propose Caps on Emissions (July 11, 2007), available at http://www.nytimes.com/aponline/us/AP-Climate-Bill.html

${ }^{100}$ Defended as the best approach in Nordhaus, supra note.
} 
regional “cap-and-trade” plan to reduce power plant emissions. ${ }^{101}$ The mayors of over 200 cities, including over 43 million Americans, have pledged to meet city-level goals corresponding with the requirements of the Kyoto Protocol. ${ }^{102}$ In June 2005, Governor Arnold Schwarzenegger pledged to reduce California's greenhouse gas emissions to 1990 levels by 2020, a pledge that helped lead to the West Coast Governor's Global Warming Initiative, which includes California, Washington, and Oregon. ${ }^{103}$ California has enacted legislation to reduce emissions of greenhouse gases from automobiles, with a $22 \%$ reduction target by 2012 and a 30\% reduction target by $2016 .^{104}$

If the analysis thus far is correct, these proposals and steps are indeed puzzling. Why do national legislators support unilateral measures that would cost a significant amount but deliver relatively small domestic benefits? Why do state officials favor steps that would do essentially nothing to reduce the problem of climate change, but that would impose real costs on their citizens? I will attempt to answer these questions below.

\section{B. Self-Interest}

The most obvious solution would show that the numbers given above are outdated, misleading, incomplete, or simply wrong. Suppose that it could be established that the United States and China do, in fact, have a great deal to lose from climate change. ${ }^{105}$ Suppose that both nations could be convinced that the likely damage is very serious, far more so than the foregoing figures suggest. ${ }^{106}$ In that event, the problem of unfortunate incentives would be greatly reduced. It should be clear that many of those interested in counteracting the problem of climate change have attempted to alter those incentives in exactly this way, by pointing to worst-case scenarios from which the United States would be greatly threatened. ${ }^{107}$ Available incidents, such as Hurricane Katrina, might well heighten concern within the United States. ${ }^{108}$ But an obvious question is whether sustained analysis might support that concern.

\footnotetext{
${ }^{101}$ See www.rggi.org

102 See www.ci.seattle.was.us/mayor.climate. For information on the Kyoto Protocol in general, see Nordhaus and Boyer, supra note; http://unfccc.int/2860.php

103 See www.ef.org/westcoastclimate

${ }^{104}$ See Abassi, supra note, at 21.

105 See Frumhoff, supra note.

106 See, e.g., id.; Stern Review, supra note, at 157.

107 See Al Gore, An Inconvenient Truth (2006).

108 See Cass R. Sunstein, Worst-Case Scenarios (2007) (emphasizing power of available incidents).
} 
1. Risks. Some projections do suggest that the United States may well have a great deal to lose. For catastrophic events, consider the following table ${ }^{109}$ :

Table 11

Percentage Loss of GDP from Catastrophic Warming

\begin{tabular}{|l|l|}
\hline United States & 22.1 \\
\hline China & 22.1 \\
\hline Japan & 22.1 \\
\hline OECD Europe & 44.2 \\
\hline Russia & 33.2 \\
\hline India & 44.2 \\
\hline Eastern Europe & 22.1 \\
\hline Africa & 22.1 \\
\hline
\end{tabular}

If the risk of catastrophe is perceived as high, ${ }^{110}$ the threat to China and the United States becomes far more severe - comparable, in fact, to the threats to Japan and Africa.

For the United States, some pessimistic scenarios do suggest significant risks well short of catastrophe. A "business as usual" approach has been projected to create exceedingly serious problems for the Northeast, including increased flooding, adverse effects on agriculture, and serious health problems. ${ }^{111}$ One high climate change scenario projects an annual average of 13,080 additional deaths during the period 2000-2100. ${ }^{112}$ Because motor vehicle accidents produce over 40,000 each year, 13,080 may not appear so alarmingly high; but to put it vividly, this figure suggests that climate change would ensure, each year, deaths equivalent to those that would come from six attacks on the order of those of September 11, 2001. A similarly pessimistic scenario suggests 39 percent average annual percentage decreases in agricultural productivity and 31.3 percent average annual percentage increases in water costs. ${ }^{113}$ To the extent that science converges on figures of this sort, the United States will have a much stronger incentive to seek an international agreement. And if low discount rates are used, annual GDP losses for developed nations as a whole have been projected at about 5 percent and possibly

\footnotetext{
${ }^{109}$ Nordhaus and Boyer, supra note, at 90 . For a technical discussion of the importance of considering uncertainty and catastrophe, see Martin Weitzman, Structural Uncertainty and the Value of a Statistical Life in the Economics of Catastrophic Climate Change (2007), available at http://www.aeibrookings.org/publications/abstract.php?pid=1196

110 National Research Council, Abrupt Climate Change: Inevitable Surprises (2004); Avoiding Dangerous Climate Change (Hans Schellnuber et al. eds 2006).

${ }^{111}$ See Frumhoff, supra note. Note, however, that this highly illuminating effort does not seriously attempt to quantify the various adverse effects.

112 Jorgenson et al., at 9.

${ }^{113}$ Id.
} 
higher by 2100. ${ }^{114}$ Of course a longer time horizon, projecting until (say) 2200, will find correspondingly more serious risks, if only because of increased warming under “business as usual” approaches.

There are other possibilities. Emissions reductions might produce an array of ancillary benefits. Emissions limitations might yield a "national security dividend," stemming from decreased reliance on foreign oil. ${ }^{115}$ To the extent that this dividend can be monetized, or at least included in the overall analysis, emissions reductions might seem more desirable even if the climate change gains are fairly modest. An international accord might also promote commercial opportunities for American firms, not least in connection with emissions trading and technology transfer. ${ }^{116}$ And to the extent that United States participation in such an accord might provide strategic benefits, by allowing bargaining on a number of related issues (including the war against terrorism), the argument on its behalf is evidently stronger. ${ }^{117}$

Detailed studies of the potential effects of climate change do not appear to exist for China, but many scenarios suggest significant harm. ${ }^{118}$ A national report in 2007, China's National Climate Change Programme, ${ }^{119}$ suggests a range of serious risks, including rising sea levels, greater desertification, retreat of glaciers, and more frequent occurrence of extreme weather/climate events including floods and droughts, with large adverse effects on socio-economic development. To the extent that findings of this kind suggest that China has a great deal at stake, the incentive to join an international agreement will obviously increase.

2. Decreased costs. The United States was the leading producer of ozonedepleting chemicals, suggesting that the United States would be most likely to resist strong controls on such chemicals. But as the controversy intensified, the incentives of American companies turned out to be radically different from what many people anticipated. A key reason is that DuPont, the principal American producer of CFCs, was

\footnotetext{
114 See Stern Review, supra note.

115 See Mignone, supra note.

116 See Stewart and Wiener, supra note, at 47-50.

117 Stewart and Wiener, supra note, at 51.

118 See Stern Review, supra note, at 157; a range of relevant papers can be found at http://search.treasury.gov.uk/search?p=Q\&ts=treasury\&mainresult=mt_mainresult_yes\&w=china

${ }^{119}$ Available at http://www.ccchina.gov.cn/en/
} 
able to develop relatively inexpensive substitutes. ${ }^{120}$ As a result, DuPont actually had an incentive to favor aggressive regulation of ozone-depleting chemicals, because such regulation could increase its market share. Because DuPont expected to turn out to be the leading producer of CFC substitutes, aggressive regulation was in its interest.

More generally, American producers saw that good commercial opportunities lay in the development and marketing of new products for which they had a comparative advantage over foreign producers. ${ }^{121}$ Consider the companies' warning "that international cooperation was essential, and that participation in an agreement to phase out CFCs needed to be as broad as possible, to avoid production by other manufacturers relocating to non-signatory states.” ${ }^{\text {} 22}$ It is noteworthy in this regard that the European Community speculated that the Reagan Administration's support for aggressive controls was driven by the fact that American producers had “developed substitutes.”123

This example suggests a promising possibility: Perhaps the United States or (less likely) China will innovate, ensuring that domestic companies will benefit from aggressive regulation of greenhouse gases. If one or another nation believes that it is innovating, or might innovate, in a way that will produce significant economic benefits from aggressive regulation, the argument for greenhouse gas reductions will be doubly strengthened. First, the cost of such reductions will decrease. Second, a nation's companies might actually gain if other nations are looking for less expensive substitutes. To be sure, there is no evidence, to date, that this will occur nearly as quickly or easily for greenhouse gases as it did in the context of ozone-depleting chemicals. ${ }^{124}$ But technology-forcing efforts have not been seriously ventured in the United States, and they might well produce valuable innovations. ${ }^{125}$

Return in this regard to California's aggressive emissions reduction initiative, ${ }^{126}$ which is not easy to justify on conventional cost-benefit grounds. ${ }^{127}$ Standing

${ }^{120}$ See Sunstein, Of Montreal and Kyoto, supra note.

${ }^{121}$ Id.

122 Scott Barrett, Environment \& Statecraft 234 (2005).

123 James Hammitt, Stratospheric-Ozone Depletion, in Economic Analyses At EPA 131, 157 (Richard Morgenstern ed. 1997).

${ }^{124}$ See Sandler, supra note.

125 See Richard A. Posner, Catastrophe: Risk and Response (2005).

126 Robert Stavins et al., Too Good to be True? An Examination of Three Economic Assessments of California’s Climate Change Policy (2007), available at http://www.aei-brookings.org/publications/abstract.php?pid=1151 
by itself, the California initiative will cost a significant amount but deliver few benefits to California or the world. ${ }^{128}$ (Recall the reason: If California reduces its own emissions, and the rest of the world does not do the same, the impact on climate change will be close to zero. ${ }^{129}$ ) One argument in favor of California's initiative is that it will stimulate innovation that will ultimately benefit the innovators, which, it is hoped, will be in California. More generally, the costs of regulation often turn out to be lower than anticipated. ${ }^{130}$ Perhaps the projections for the United States and China are inflated, simply because technological innovations will drive down the cost of compliance. If this is so, and if prominent officials can be persuaded that it is so, the likelihood of a regulatory response will be increased.

Some evidence supports the view that the costs might be significantly lower than expected. The Intergovernmental Panel on Climate Change estimates that global emissions could be reduced 15\% below their year-2000 levels using nothing but existing technology at a negative or zero net cost. ${ }^{131}$ On this admittedly optimistic (and probably unrealistic) account, ${ }^{132}$ the energy savings would pay for themselves. There is also evidence that promising technologies could significantly decrease the costs of stabilizing the concentration of greenhouse gases in the atmosphere. For example, carbon capture and storage (CCS) is an existing technology that, if deployed on a global scale, could decrease the cost of stabilizing atmospheric concentrations of carbon at $450 \mathrm{ppm}$ by the year 2100 by as much as $40 \% .{ }^{133}$ CCS involves the capture of CO2 from a fixed source, such as a coal-fired power plant, and the long-term storage of that CO2 deep underground or in the ocean. ${ }^{134}$ This approach would have large advantages for China, which could

127 See id.

128 Id.

${ }^{129}$ See the emphasis on the need for broad participation in Nordhaus, supra note; Stewart and Wiener, supra note.

${ }^{130}$ It is often thought that the costs of environmental regulations are wildly exaggerated, before the fact, and that they turn out to be much lower than projected. See, e.g., David Driesen, Economic Dynamics of Environmental Law, 31 BC Env Aff L Rev 501, 516 (2004). The reality is more complicated. See John Graham, Lifesaving Regulation: Enhancing the Role of Benefit-Cost Analysis 102-107 (unpublished manuscript 2007).

131 Intergovernmental Panel On Climate Change Working Group III. IPCC Special Report: Carbon Capture and Storage (2005).

${ }_{132}$ Compare Nordhaus, supra note.

133 Christian Azar et al., Carbon Capture and Storage From Fossil Fuels and Biomass - Costs and Potential Role in Stabilizing the Atmosphere, 74 Climatic Change 47 (2006).

134 Id. 
continue using its coal-fired power plants while reducing emissions by perhaps as much as $90 \%{ }^{135}$

CCS remains a highly speculative possibility; it is currently unknown whether the geological storage capacity exists on the global scale needed to deploy this technology, and there are risks of leakage of CO2 from the storage sites. ${ }^{136}$ But if these problems can be overcome, the costs of mitigation could become low enough to make aggressive reductions far more attractive.

3. Special provisions and side-payments. I have noted that if the world stands to gain from an emissions control agreement, and if China and the United States believe that they stand to lose, the efficient solution is clear. The world should reach an agreement that produces the optimal reductions, and China and the United States should be compensated for their willingness to participate in that agreement. No one is now suggesting that the United States should receive such compensation. But it has indeed been suggested that China might have to be "paid to play."137 And with respect to China, it turns out that there is at least a partial precedent for this solution.

In the context of ozone-depleting chemicals, the developing countries were initially skeptical about the idea that they should be subject to the restrictions of the Montreal Protocol. ${ }^{138}$ Their skepticism was easy to defend by reference to domestic selfinterest. For poor nations, such restrictions would impose significant costs for speculative gains. Self-interest aside, such nations plausibly contended that they should not be subjected to the same controls as wealthier nations, which were responsible for the problem in the first place. India and China emphasized that nations with less than 25 percent of the world's population had been responsible for over 90 percent of the world's CFCs. $^{139}$

But wealthy nations could not easily be content with an agreement excluding developing countries. While CFC consumption was low in those countries, their domestic requirements were increasing, ${ }^{140}$ and a badly designed agreement could merely shift the production and use of CFCs from wealthy nations to poorer ones, leaving the global

\footnotetext{
135 See IPCC WGIII, supra note.

${ }^{136}$ Id.

137 Stewart and Wiener, supra note, at 15.

138 See Sunstein, Of Montreal and Kyoto, supra note.

139 Percival et al., supra note, at 1052.

${ }^{140}$ Benedict, supra note, at 93.
} 
problem largely unaffected. The ultimate resolution was to overcome the resistance of the developing nations with several steps, including both loosened restrictions and financial assistance. Under Article 5 of the Montreal Protocol, developing countries are authorized to meet "basic domestic needs" by increasing to a specified level for ten years, after which they are subject to a 50 percent reduction for the next ten years. In addition, a funding mechanism was created by which substantial resources—initially $\$ 400$ millionwere transferred to poor countries. ${ }^{141}$

Might it be possible to build on these ideas for climate change ${ }^{142}$ ? Let us focus on China, which presents the easier case. Suppose that a worldwide carbon tax would be desirable, ${ }^{143}$ but that China resists taking action that would mostly benefit other nations. If so, it would not be at all surprising if wealthy nations decided to make special provision for China (and other developing nations). ${ }^{144}$ In 2001, the Marrakech accords led to innovations from the Kyoto Protocol, in which developing countries were made beneficiaries of funds to assist with technology transfer. ${ }^{145}$ Although the level of the funds remains unspecified, donors led by the European Union pledged to grant $\$ 410$ million annually. ${ }^{146}$ For China's participation, the most promising route would be to take steps to make emissions reduction in that nation's self-interest. We could imagine four possibilities here: (a) technology transfers; (b) extended compliance periods, ${ }^{147}$ building on the Kyoto Protocol; (c) allocation of large initial emissions rights, perhaps based partly on per capita emissions, that would reduce the overall $\operatorname{cost}^{148}$; and (d) direct cash payments. The most obvious solution might well be (c), in the form of "headroom allowances," giving China a range of rights that it can trade to wealthy nations or hold itself in the event of continuing spurts in economic growth. ${ }^{149}$

Efforts to compensate China for emissions reductions are closely analogous to other measures through which the victims of pollution are asked to pay a polluter to

\footnotetext{
${ }^{141}$ See id,; see also Bowser, History of the Montreal Protocol’s Ozone Fund, 14 Intl Env Rep 636 (1991).

142 See Olmstead and Stavins, supra note.

143 See Nordhaus, supra note.

144 See id.

145 See id. at 1072-73; Vespa, Climate Change 2001: Kyoto at Bonn and Marrkech, 29 Ecol. L. Q. 395 (2002).

${ }^{146}$ Percival et al., at 1073.

${ }^{147}$ Olmstead and Stavins, supra note.

148 This was the strategy taken in the Kyoto Protocol with Russia. See Nordhaus and Boyer, supra note, at 162.

${ }^{149}$ See Stewart and Wiener, supra note, at 15.
} 
reduce its polluting activity. ${ }^{150}$ Under certain circumstances, this approach is efficient, in the sense that it will produce the optimal activity level, and also desirable from the standpoint of distributional equity, because the polluters (and those who benefit from polluting activity) are less wealthy than are the victims. For a mundane example, consider the idea of "cash for clunkers," by which owners of old, high-polluting vehicles are paid to retire their cars. The owners of such cars are disproportionately poor, and hence the relevant programs might be defended on distributional grounds at the same time that they promote social welfare.

On plausible assumptions, this is a sensible approach to take to climate change. To be sure, it is possible to object on grounds of corrective justice: Why should the victims of pollution be asked to pay polluters to get them to stop? Why should the world pay China to persuade it to cease imposing risks on the rest of the world? Such questions might be decisive in the context of intentional or reckless wrongdoing, but they may well point in the wrong direction in the context of the unintended side-effects of otherwise desirable activity. ${ }^{151}$ Imagine, for example, that a company in New York is employing large numbers of poor workers, who would lose their jobs if the company were forced to close; imagine too that the company's actions produce pollution that harms the wealthiest people in (say) Albany. It might well be best to ask the wealthy citizens of Albany to pay the company, and its workers, to cease their activity. ${ }^{152}$ Indeed, if China's relatively low per-capita emissions are taken into account, it might be tempting to argue that those who emit more on a per capita basis have a moral obligation to compensate China for its reductions.

But if distributional considerations are kept in mind, there is an evident complication here. Many citizens of China are wealthy, and many citizens of (say) Africa, India, Germany, and France are poor. If distributional considerations are what matter, it is not at all clear that the citizens of the world should pay the citizens of China to reduce their emissions. ${ }^{153}$ Even if the paying nations were mostly wealthy, it remains true that millions of citizens of wealthy nations are poor, and a payment from (say) the

\footnotetext{
${ }^{150}$ See Guido Calabresi and A. Douglas Melamed, Property Rules, Liability Rules, and Inalienability: One View of the Cathedral, 85 Harv L Rev 1089 (1972).

151 For detailed discussion, see Eric A. Posner and Cass R. Sunstein, Climate Change Justice (unpublished manuscript 2007).

${ }^{152}$ See the classic discussion in Calabresi and Melamed, supra note.

${ }^{153}$ For general discussion, see Posner and Sunstein, supra note.
} 
United States, the United Kingdom, Australia, and Canada to China might well hurt millions of poor people. On the other hand, it would be easy to imagine a side-payment, or an allocation of emissions rights, that was generally desirable on distributive grounds, even if it did not operate as a pure or simple transfer from rich to poor.

Now turn to the United States. On efficiency grounds, the analysis is the same as for China. If the United States would be a net loser from an international agreement, the United States might be compensated for its participation. But the analysis of distributional issues is different. The United States has the one of the highest per capita income rates on the planet, and the citizens of India, Africa, Germany, and France are not likely to want to pay the United States to scale back its emissions. Of course the United States is not a person, and perhaps poor Americans would benefit from such payments. On the other hand, there is a clear and probably decisive pragmatic obstacle to any claim that the United States should be paid for its participation: Other nations are most unlikely to be willing to do that. But an analysis of the underlying issues requires a direct engagement with the moral issues.

\section{Moral Considerations}

Suppose that for one or another reason, the United States and China do conclude that they have comparatively little to lose from climate change, and that aggressive emissions restrictions would impose significant economic burdens on them. Suppose too that climate change will impose severe harm on many nations, causing (for example) millions of premature deaths in Africa and India. If so, there remains a strong argument that the United States and China should reduce their emissions, regardless of how much the citizens in the United States and China have to gain from those reductions. ${ }^{154}$ The adverse effects on Africa and India might even be considered a tort, in the form of a nuisance imposed on them by the United States and China. ${ }^{155}$ For example, energy and gasoline prices in the United States have been far lower than they would have been if those prices had included an amount attributable to the increased risks of climate change.

\footnotetext{
154 Dale Jamieson, Adaptation, Mitigation, and Justice, in Perspective on Climate Change: Science, Economics, Politics, Ethics 217 (Walter Sinnott-Armstrong and Richard Howarth eds. 2005); Julia Driver, Ideal Decision Making and Green Virtues, in id. at 249.

${ }^{155}$ For an ambivalent discussion of the tort analogy, see Posner and Sunstein, supra note.
} 
Perhaps the United States and China might be persuaded to act on the ground that they have a moral obligation to do so.

Within the United States, many billions of dollars are spent each year on foreign aid, ${ }^{156}$ and an international agreement to control global environmental problems might operate as a form of such aid. Perhaps the United States might be willing to compensate developing nations for the costs of reducing greenhouse gas emissions, and to provide aid for them. There can be little doubt that with respect to domestic climate change initiatives in the United States, a perception of moral obligations has played a significant role. ${ }^{157}$ There seems to be an unruly combination of arguments from corrective justice and arguments from distributional equity.

We can make some progress here by noticing that in three ways, the analysis of the moral obligations of the United States is different from the corresponding analysis for China. First, the United States has contributed far more to the existing "stock" of greenhouse gases. ${ }^{158}$ Even if its contributions will be lower than those of China in the future, the significant American contribution to the stock must be taken into account. This is a point about corrective justice. Second, the United States is much richer than China, and ability to pay is surely relevant to the overall assessment. This is a point about distributive justice. I have noted that because the United States is wealthier than China, it is more likely to reduce risks that will come to fruition in the future; for the same reason, the United States might be thought to be under a special obligation to protect those nations that most threatened. Third, the United States has by far the highest per capita emission rate, and it is plausible to think that the per capita rate is relevant to a nation's moral obligations. We have seen that while China is the largest emitter of any nation, its per capita emissions rate rank it far below many nations. None of this means that China is not obliged to take action as well. But China might well resist the claim that its obligations are akin to those of the United States.

\footnotetext{
156 See Congressional Research Service, Foreign Aid: An Introductory Overview of U.S. Programs and Policy (January 19, 2005) (reporting, among other things, $\$ 7.35$ billion for development assistant, id. at 4, and $\$ 2.68$ billion in humanitarian assistance, id. at 6).

157 See notes supra.

158 See Table 8, supra.
} 
The analysis of moral obligations must disentangle the three considerations referred to above. ${ }^{159}$ The obligations of wealthy nations present a simple question of distributional fairness; the climate change setting is not unique on that count. It may well be true that the United States should be transferring significant sums of money to China, or to poor people in China, but it is not doing so. This point suggests a clear political constraint on the use of distributive arguments as a basis for policy. In any case there is an intergenerational question here, one that complicates distributional arguments in the context of climate change: People in the future will almost certainly be wealthier than people in the present. ${ }^{160}$ If the United States seeks to distribute resources to poor people in India and Africa, there is a much stronger argument for distributing resources to poor people now living in India and Africa than for distributing to future poor people in India and Africa. On the other hand, it remains true that if redistribution from rich to poor is desirable, climate change policy might serve, if crudely, to promote that goal.

The question of past contributions raises separate issues. ${ }^{161}$ To simplify the analysis, let us begin by assuming that nations should be treated as if they were people with very long lives. With this assumption, it makes sense to come to terms with past contributions by asking nations to participate in the creation of some kind of fund for climate change damages, with their participation reflecting their contributions to the total existing stock of emissions. China need not contribute much to such a fund; the United States would be required to contribute a great deal. A step of this kind would be a sensible response to the fact, shown by the table above, that different nations have added dramatically different amounts to the current situation. A separate step would involve the response to existing flows. Perhaps a "polluters pay" principle could be made a part of an international agreement, so that nations would pay an amount to reflect their continuing contributions. ${ }^{162}$

This approach to past emissions "stocks" does elide two important problems. ${ }^{163}$ The first is that most of the emissions by the United States occurred in periods in which

\footnotetext{
${ }^{159}$ For detailed discussion, see Posner and Sunstein, supra note.

${ }^{160}$ Remarks of Thomas C. Schelling in Global Crises, Global Solutions, supra note, at 627.

${ }^{161}$ See the excellent brief discussion in Jagdish Bhagwati, Global Warming Fund Could Succeed Where Kyoto Failed, Financial Times (Aug. 16, 2006), on which I draw here.

${ }^{162}$ See Bhagwati, supra note.

${ }^{163}$ I am grateful to Eric Posner for this insight. For valuable discussion, see Eric Posner and Adrian Vermeule, Reparations for Slavery and Other Historical Injustices, 103 Colum L Rev 689 (2003).
} 
the United States did not know or have reason to know of the risk of harm. Should climate change be seen as a kind of strict liability tort, or must some kind of negligence be shown? The second problem is that many of the beneficiaries of greenhouse gas emissions, in the United States, are long dead. Should their descendents have to pay for those emissions? Perhaps the answer is yes, if those descendants have benefited from the emissions. But is it so clear that current Americans are beneficiaries of emissions from (say) 1900-1950, such that they should be expected to pay the citizens of the world for those contributions? In this respect, the climate change problem has some overlap with seemingly unrelated domains in which reparations are sought from the descendants of wrongdoers. ${ }^{164}$ It is not clear, in short, that the idea of corrective justice is well-suited to climate change. $^{165}$

The question of whether per capita emissions should be taken into account presents thorny ethical and pragmatic problems. China argues that any international agreement should consider the fact that its large aggregate emissions disguise the fact that its per capita emissions rate is not terribly high. We have seen that nations are not people and it is highly artificial to say that a nation with a large population should be allocated the same emissions rights as a nation with a much smaller population. It is clear that the United States would not accept any agreement in which emissions rights are allocated on a per capita basis. But it is also clear that China's immense population, and its comparatively low per capita emissions rate, might well be relevant to a bargain. The problem is that any effort to base an international agreement on per capita rates is really a claim for large-scale redistribution across nations, and it is not clear why the United States should agree to such redistribution if it is not doing so already - especially to the extent that the United States does not perceive itself as gravely threatened by climate change.

\section{Of Confusion, Hope, and Morality}

Notwithstanding the thrust of my argument here, aggressive action by the United States, and indeed unilateral action, would not exactly be a stunning surprise. Indeed, it is reasonable to predict that such action will occur, at the national level, in the

\footnotetext{
164 See id.

165 See Posner and Sunstein, supra note.
} 
next few years. Recall that unilateral action has already obtained considerable support in Congress. Recall too that California has required significant steps on its own, even though the cost is likely to be significant and the benefits are likely to be essentially zero. How can such support, and California’s actual legislation, be plausibly explained?

The best answer points to the relationship between moral considerations and a mixture of confusion and hope. In many domains, the problem on which I have been focusing is not widely understood; many people appear not to appreciate the fact that significant steps, by states or even regions, will have no significant impact on climate change. On one estimate, the Kyoto Protocol was expected to reduce warming by only 0.03 C by 2100 , even though many nations were involved ${ }^{166}$; a key reason is that the Kyoto Protocol does not control the explosive growth in emissions from developing nations. It follows that by itself, California's initiative will do exceedingly little to reduce warming. It is not at all clear that those who supported the initiative appreciated that fact.

But there is a hope here, not merely confusion. The hope is reflected in the thought that if California acts, other states might do so as well, eventually to be followed by the nation as a whole, and eventually by other nations as well. Perhaps a single state, or at least one as large as California, can start a cascade. ${ }^{167}$ Many of those who call for unilateral action by the United States might know that by itself, such action will do very little about the anticipated warming. They might well believe that the developing nations, most importantly China, are most unlikely to act if the United States does not do so, and that action by the United States is an indispensable start toward an agreement of the sort that is generally believed to be in the world's interest. ${ }^{168}$ On this view, a cap-and-trade program by the United States might be the beginning of an implicit deal, in the form of a showing of good faith, to which other nations might eventually respond.

Note in this connection that unilateral action has the advantage of being reversible. California's emissions reductions requirements need not be met until 2025. If the cost of meeting the requirements turns out to high, if no cascade has started, and if the science looks less favorably on aggressive action, the requirements can be relaxed or

\footnotetext{
${ }^{166}$ See Nordhaus and Boyer, supra note, at 152. A more optimistic estimate finds that the Kyoto Protocol might reduce global warming by as much as $0.28 \mathrm{C}$ by 2100 . See Stewart and Wiener, supra note, at $45-46$.

${ }^{167}$ On cascades in general, see Sushil Bikchandani et al., Learning From the Behavior of Others: Conformity, Fads, and Informational Cascades, $12 \mathrm{~J}$ Econ Persp 151 (1998); on cascades at the level of nations, see Eric Posner and Cass R. Sunstein, The Law of Other States, 59 Stan L Rev 131 (2006).

${ }^{168}$ See Nordhaus, supra note; Olmstead and Stavins, supra note; Frumhoff, supra note.
} 
eliminated. The United States might itself adopt an aggressive emissions reductions program on the explicit or implicit assumption that other nations, including the developing ones, will act as well. If no such action is forthcoming, the American program might become more lenient.

To these points it might be added that unilateral action could spur technological innovation that would be in the interest of the United States as well as the world as a whole. ${ }^{169}$ Because the United States is quite wealthy, what might otherwise be a significant "investment" in the reduction of the risk of climate change might not be so damaging. For those who believe that national policy should be based on domestic selfinterest, there is an evident problem with these arguments for unilateral action: Even if international action does follow, it is not clear that the domestic benefits of greenhouse gas reduction would justify the domestic costs. But for reasons explored above, the existing numbers, raising doubts about the domestic cost-benefit analysis, may not be the right ones.

\section{Conclusion}

If the world consisted of simply one nation, it would probably have little difficulty in settling on significant reductions in greenhouse gas emissions, either through a cap-and-trade system ${ }^{170}$ or (possibly better still ${ }^{171}$ ) through a carbon tax. And if the world's leading emitters also had a great deal to lose from climate change, the problem would be more tractable, simply because those nations would seek an international accord. The easiest situation would be one in which the principal emitters would gain from unilateral action, as in the context of ozone-depleting chemicals. The problem of climate change does not have this characteristic. Neither the United States nor China would gain much from unilateral action, which would also impose significant costs. On existing projections, the two nations' complex incentives raise questions about participation in an international agreement that requires large reductions; and both nations' actions to date reflect the power of those incentives. Perhaps these projections are wrong, but they continue to shape climate change policy in both nations. The United

\footnotetext{
169 See Richard A. Posner, Catastrophe: Risk and Response (2005).

170 See Stewart and Wiener, supra note.

${ }^{171}$ See Nordhaus, supra note.
} 
States and China might reasonably believe that an agreement that is optimal for the world is not optimal for the United States and China.

It is obvious that the United States and China would be more likely to participate in an international agreement if the perceived costs decreased or if the perceived benefits increased. The simplest way to decrease the perceived costs would involve technological innovation, for example via energy sources that do not produce high levels of carbon emissions. The simplest way to increase the perceived benefits would involve clearer evidence of significant losses for both nations; if the risk of catastrophic outcomes is perceived as real, the benefits assessment would change accordingly. ${ }^{172}$ Ancillary benefits, involving (for example) energy self-sufficiency and national security, could also alter the calculus.

It is far from clear that either the United States or China would be willing to sacrifice large sums of money simply because of a perception of their moral obligations. But there can be no doubt that a sense of moral obligation is playing a significant role in both national and international debates, especially with respect to the actions of the United States. Because the citizens of Africa and India have a great deal to lose, and indeed because millions of lives are at risk, there is good reason for the United States and China to act whether or not such action is in their self-interest. ${ }^{173}$ Because of its wealth, its high per capita emissions rate, and its past contributions, the moral obligations of the United States are especially insistent. What remains clear is that the United States cannot do much about the problem without the participation of developing countries, above all China. For this reason, it is appropriate for the United States to take active steps, perhaps including unilateral action, in order to increase the likelihood that such countries will be willing to participate in the future.

Readers with comments should address them to:

Professor Cass R. Sunstein

University of Chicago Law School

1111 East 60th Street

Chicago, IL 60637

csunstei@midway.uchicago.edu

\footnotetext{
172 See supra.

${ }^{173}$ Note that financial help with adaptation might well supplement emissions reductions. See note supra; see also Stern Review, supra note, at 622-638.
} 


\section{Chicago Working Papers in Law and Economics (Second Series)}

For a listing of papers 1-299 please go to Working Papers at http://www.law.uchicago.edu/Lawecon/index.html

300. $\quad$ Adam B. Cox, The Temporal Dimension of Voting Rights (July 2006)

301. Adam B. Cox, Designing Redistricting Institutions (July 2006)

302. Cass R. Sunstein, Montreal vs. Kyoto: A Tale of Two Protocols (August 2006)

303. Kenneth W. Dam, Legal Institutions, Legal Origins, and Governance (August 2006)

304. Anup Malani and Eric A. Posner, The Case for For-Profit Charities (September 2006)

305. Douglas Lichtman, Irreparable Benefits (September 2006)

306. M. Todd Henderson, Paying CEOs in Bankruptcy: Executive Compensation when Agency Costs Are Low (September 2006)

307. Michael Abramowicz and M. Todd Henderson, Prediction Markets for Corporate Governance (September 2006)

308. Randal C. Picker, Who Should Regulate Entry into IPTV and Municipal Wireless? (September 2006)

309. $\quad$ Eric A. Posner and Adrian Vermeule, The Credible Executive (September 2006)

310. David Gilo and Ariel Porat, The Unconventional Uses of Transaction Costs (October 2006)

311. Randal C. Picker, Review of Hovenkamp, The Antitrust Enterprise: Principle and Execution (October 2006)

312. Dennis W. Carlton and Randal C. Picker, Antitrust and Regulation (October 2006)

313. Robert Cooter and Ariel Porat, Liability Externalities and Mandatory Choices: Should Doctors Pay Less? (November 2006)

314. Adam B. Cox and Eric A. Posner, The Second-Order Structure of Immigration Law (November 2006)

315. Lior J. Strahilevitz, Wealth without Markets? (November 2006)

316. Ariel Porat, Offsetting Risks (November 2006)

317. Bernard E. Harcourt and Jens Ludwig, Reefer Madness: Broken Windows Policing and Misdemeanor Marijuana Arrests in New York City, 1989-2000 (December 2006)

318. Bernard E. Harcourt, Embracing Chance: Post-Modern Meditations on Punishment (December 2006)

319. Cass R. Sunstein, Second-Order Perfectionism (December 2006)

320. William M. Landes and Richard A. Posner, The Economics of Presidential Pardons and Commutations (January 2007)

321. Cass R. Sunstein, Deliberating Groups versus Prediction Markets (or Hayek’s Challenge to Habermas) (January 2007)

322. Cass R. Sunstein, Completely Theorized Agreements in Constitutional Law (January 2007)

323. Albert H. Choi and Eric A. Posner, A Critique of the Odious Debt Doctrine (January 2007)

324. Wayne Hsiung and Cass R. Sunstein, Climate Change and Animals (January 2007)

325. Cass. R. Sunstein, Cost-Benefit Analysis without Analyzing Costs or Benefits: Reasonable Accommodation, Balancing and Stigmatic Harms (January 2007)

326. Cass R. Sunstein, Willingness to Pay versus Welfare (January 2007)

327. David A. Weisbach, The Irreducible Complexity of Firm-Level Income Taxes: Theory and Doctrine in the Corporate Tax (January 2007)

328. Randal C. Picker, Of Pirates and Puffy Shirts: A Comments on "The Piracy Paradox: Innovation and Intellectual Property in Fashion Design” (January 2007)

329. Eric A. Posner, Climate Change and International Human Rights Litigation: A Critical Appraisal (January 2007)

330. Randal C. Picker, Pulling a Rabbi Out of His Hat: The Bankruptcy Magic of Dick Posner (February 2007)

331. Bernard E. Harcourt, Judge Richard Posner on Civil Liberties: Pragmatic (Libertarian) Authoritarian (February 2007)

332. Cass R. Sunstein, If People Would Be Outraged by Their Rulings, Should Judges Care? (February 2007)

333. Eugene Kontorovich, What Standing Is Good For (March 2007)

334. Eugene Kontorovich, Inefficient Customs in International Law (March 2007)

335. Bernard E. Harcourt, From the Asylum to the Prison: Rethinking the Incarceration Revolution. Part II: State Level Analysis (March 2007)

336. Cass R. Sunstein, Due Process Traditionalism (March 2007)

337. Adam B. Cox and Thomas J. Miles, Judging the Voting Rights Act (March 2007)

338. M. Todd Henderson, Deconstructing Duff \& Phelps (March 2007)

339. Douglas G. Baird and Robert K. Rasmussen, The Prime Directive (April 2007)

340. Cass R. Sunstein, Illusory Losses (May 2007)

341. Anup Malani, Valuing Laws as Local Amenities (June 2007)

342. David A. Weisbach, What Does Happiness Research Tell Us about Taxation? (June 2007)

343. David S. Abrams and Chris Rohlfs, Optimal Bail and the Value of Freedom: Evidence from the Philadelphia Bail Experiment (June 2007)

344. Christopher R. Berry and Jacob E. Gersen, The Fiscal Consequences of Electoral Institutions (June 2007) 
345. Matthew Adler and Eric A. Posners, Happiness Research and Cost-Benefit Analysis (July 2007)

346. Daniel Kahneman and Cass R. Sunstein, Indignation: Psychology, Politics, Law (July 2007)

347. Jacob E. Gersen and Eric A. Posner, Timing Rules and Legal Institutions (July 2007)

348. Eric A. Posner and Adrian Vermeule, Constitutional Showdowns (July 2007)

349. Lior Jacob Strahilevitz, Privacy versus Antidiscrimination (July 2007)

350. Bernard E. Harcourt, A Reader's Companion to Against Prediction: A Reply to Ariela Gross, Yoram Margalioth, and Yoav Sapir on Economic Modeling, Selective Incapacitation, Governmentality, and Race (July 2007)

351. Lior Jacob Strahilevitz, “Don’t Try This at Home”: Posner as Political Economist (July 2007)

352. Cass R. Sunstein, The Complex Climate Change Incentives of China and the United States (August 2007) 